Review

\title{
Urban forest research in the Mediterranean: A systematic review
}

\author{
Silvija Krajter Ostoićc ${ }^{\mathrm{a}, *}$, Fabio Salbitano $^{\mathrm{b}}$, Simone Borelli $^{\mathrm{c}}$, Andrej Verlič ${ }^{\mathrm{d}}$ \\ ${ }^{a}$ Croatian Forest Research Institute, Department for International Scientific Cooperation in Southeast Europe - EFISEE, Perkovčeva 5/II, 10 000 Zagreb, Croatia \\ ${ }^{\mathrm{b}}$ University of Florence, Department of Agricultural, Food and Forestry Systems (GESAAF), Via S. Bonaventura 13, 50145 Florence, Italy \\ ${ }^{\mathrm{c}}$ Food and Agriculture Organisation of the United Nations, Forestry Policy and Resources Division, Viale delle Terme di Caracalla, 00153 Rome, Italy \\ d Slovenian Forestry Institute, Department of Forest Ecology, Večna pot 2, 1000 Ljubljana, Slovenia
}

\section{A R T I C L E I N F O}

\section{Keywords:}

Research themes

Scopus

Urban forestry

Green space

Green infrastructure

Mediterranean

\begin{abstract}
A B S T R A C T
The Mediterranean region is facing many challenges, some of which can be addressed by nature-based solutions such as urban forests and green space. However, at best, urban forest research from Mediterranean countries has been only briefly addressed in review papers up to date. This Scopus-based review paper provides first insights into the development of urban forest research in the Mediterranean in the 20-year period from 1996 to 2015. The purpose of the review was to a) analyse distribution of urban forest research in the Mediterranean and identify countries that are forerunners based on the number of publications, b) to analyse distribution of research themes across the Mediterranean and per country, and hence point to research gaps and needs. Researchers from Italy, Turkey and Spain were the most productive in the analysed period. Research is mainly concentrated in the North, while it is scarce to non-existent in South and Eastern Mediterranean countries (excluding Turkey and Greece). Papers dealing with pollution, human health and sociocultural values were the most frequent. Some countries exhibited research specialisation with regard to certain themes. For instance Italian researchers mostly focused on topics related to pollution and urban forest management, the majority of Spanish papers addressed urban forests in the context of human health, while sociocultural values were the main research theme for researchers from Turkey. Papers were analysed also based on research methods, approaches and study locations. Suggested future research includes analysis of the quality of knowledge related to urban forests in the Mediterranean as well as of collaboration between researchers, research institutions and countries.
\end{abstract}

\section{Introduction}

The Mediterranean region, home to more than half a billion people on three continents, is undergoing intensive demographic, social, cultural, economic and environmental changes (EEA, 2015). These challenges include population increase in Southern and Eastern Mediterranean countries, migration surges, armed conflicts, health issues, climate change, unsustainable urbanisation and urban sprawl in coastal areas, poor air quality, forest fires, encroachment of alien and invasive species, as well as soil degradation and biodiversity loss (FAO, 2013; Salvati and Gargiulo Morelli, 2014; UNEP/MAP, 2016; EEA, 2016; WHO, 2017). Consequently, natural resources including urban forests and green space are under great pressure and the quality of life in urban areas is decreasing. On the other hand, nature-based solutions, as an overarching concept for several approaches aiming to provide humans with various benefits by using nature (Pauleit et al., 2017), have increasingly become an important tool for addressing the complex issues that urban areas are facing (EC, 2017; Kabisch et al., 2017; Pearlmutter et al., 2017; Raymond et al., 2017). Urban forests and green spaces with their multiple services and benefits (Roy et al., 2012; Gómez-Baggethun and Barton, 2013; Krajter Ostoić et al., 2014; O’Brien et al., 2017) are the foundation of these solutions (Baró and Gómez-Baggethun, 2017). For instance, they may contribute to climate change adaptation in urban areas by draining excessive storm water, regulating climate and improving human thermal comfort (Kabisch et al., 2017) or improve the air quality (Samson et al., 2017).

One of the main strategic regional policy documents, the Mediterranean strategy for sustainable development 2016-2025, envisions "A prosperous and peaceful Mediterranean region in which people enjoy a high quality of life and where sustainable development takes place within the carrying capacity of healthy ecosystems." (UNEP/MAP, 2016). The strategy is based on six objectives, including 'Planning and managing sustainable Mediterranean cities' and 'Addressing climate change as a priority issue for the Mediterranean'. Urban forests and green spaces are part of the nature-based solutions that can contribute to achieving these goals. The strategy also calls for the scientific community to direct its research capacities in support of policymaking. However, an analysis of urban forest research in the Mediterranean is still missing.

\footnotetext{
* Corresponding author.

E-mail addresses: silvijak@sumins.hr (S. Krajter Ostoić), fabio.salbitano@unifi.it (F. Salbitano), Simone.Borelli@fao.org (S. Borelli), andrej.verlic@gozdis.si (A. Verlič).
} 
In recent years, one study and several review papers have been published on urban forest research. In their highly influential paper, James et al. (2009) provided a framework for multidisciplinary and interdisciplinary research on urban green space based on expert opinion by applying the Delphi method. As a result of the process five emerging research themes (i.e. physicality, experience, valuation, management and governance of urban green space) and 35 research questions were identified. More recent review papers addressed global scientific urban forest discourses and showed that some themes, such as managerial aspects of urban forestry (or the physicality and the management themes according to James et al., 2009), prevail, while the scientific community has focused less on policy and governance, green space in the context of urban planning and green infrastructure (Krajter Ostoić and Konijnendijk van den Bosch, 2015). In addition to these general overviews, some review papers focused on more specific aspects of urban forest research: cultural ecosystem benefits from urban and periurban green infrastructure across Europe (O'Brien et al., 2017); partnerships in urban forestry and green infrastructure (Hansmann et al., 2016); human-environment interactions (Kabisch et al., 2015); species richness in urban parks and its drivers (Nielsen et al., 2014); fear of crime in urban green space (Sreetheran and Konijnendijk van den Bosch, 2014); informal urban green space and its role for urban residents (Rupprecht and Byrne, 2014); empirical evidence of the benefits of urban parks (Konijnendijk et al., 2013); urban tree benefits, costs and assessment methods in different climatic zones (Roy et al., 2012); review of papers published in the first eight years of the Urban Forestry \& Urban Greening journal (Bentsen et al., 2010); as well as health benefits of green space and different landscape types (Di Nardo et al., 2010; Velarde et al., 2007). Besides covering various research topics, these reviews differ in terms of geographic scope, timeline and methods applied, and the objectives of the review exercise. Some review papers are written from the European perspective (O'Brien et al., 2017; Hansmann et al., 2016), while the majority have a global perspective (Velarde et al., 2007; Bentsen et al., 2010; Di Nardo et al., 2010; Roy et al., 2012; Konijnendijk et al., 2013; Nielsen et al., 2014; Rupprecht and Byrne, 2014; Sreetheran and Konijnendijk van den Bosch, 2014; Kabisch et al., 2015; Krajter Ostoić and Konijnendijk van den Bosch, 2015). However, the results showed the scarcity of urban forest research in Mediterranean countries and the prominence of different topics in different countries (Bentsen et al., 2010; Roy et al., 2012; Konijnendijk et al., 2013; Nielsen et al., 2014; Sreetheran and Konijnendijk van den Bosch, 2014; Krajter Ostoić and Konijnendijk van den Bosch, 2015). For instance, in a study on benefits of urban parks that covered 86 papers (Konijnendijk et al., 2013), health benefits were covered by 13 papers from Mediterranean countries (Egypt, Iran, Israel, Italy, Spain, Turkey), biodiversity by five (France, Israel, Italy, Spain), house prices by three (Greece, Iran and Spain); air quality and carbon sequestration by two (France, Italy) and tourism by one paper from Iran, while not a single paper addressed social cohesion or water management benefits. A review paper on cultural ecosystem benefits in Europe drew evidence from seven Mediterranean countries based on 15 out of 56 papers (seven papers from Spain, three from Turkey, two from Israel, and one each from the Former Yugoslav Republic of Macedonia, Portugal, and Serbia) (O'Brien et al., 2017), while in a review on the fear of crime in urban green space only two papers from Turkey addressed this topic (Sreetheran and Konijnendijk van den Bosch, 2014). A review on societal role of informal green space showed only one study from Italy dealing with this topic (Rupprecht and Byrne, 2014), while in reviews on health benefits of green space and different landscape types there were no studies conducted by authors from Mediterranean countries (Di Nardo et al., 2010; Velarde et al., 2007).

A comprehensive review that specifically addresses Mediterranean countries is still missing. In a global perspective and based on the results of previous review studies we can conclude that these countries are usually not considered as forerunners in urban forest research in comparison to the USA, Canada, Australia, the UK and the Scandinavian countries (Krajter Ostoić and Konijnendijk van den Bosch, 2015). We decided to investigate this assumption and see whether it applies to the entire region or whether some countries perform better than the others. We started with the following two assumptions: a) urban forest research is unevenly distributed across the Mediterranean, with most of the studies being undertaken in Northern Mediterranean countries; b) research themes vary across the Mediterranean.

Hence, the goal of the paper is a) to carry out a systematic review of urban forest research in Mediterranean countries that would identify countries that are forerunners and those where this research is emerging or non-existent, and b) to identify relevant research themes and consequently research gaps in general and per country.

\section{Methodology}

\subsection{Study area}

Due to its diversity, the region is usually divided into Northern, Southern and Eastern Mediterranean (Table 1, Fig. 1). Differences exist in terms of population size and population median age, with a rapidly increasing and younger population in Eastern and Southern Mediterranean countries. Furthermore, there are significant income disparities $^{1}$ between Northern Mediterranean countries on the one hand and Southern and Eastern Mediterranean countries on the other. However, the overall investment in Research and Development ${ }^{2}$ is increasing in most Mediterranean countries, but overall remains low (Plan Bleu, 2013; Table 1).

\subsection{Materials and methods}

Previous review papers on urban forest research discussed in the Introduction employed various methodologies implying that there is no single approach to performing a systematic review. The studies differ in terms of the number of sources used for the extraction of papers (mostly Scopus and Web of Science), the selection of key words, the inclusion of grey literature, the criteria for selection or exclusion of papers, and taking into consideration the quality of the study reported in the papers. Studies almost exclusively included papers in English, with the exception of the study by Rupprecht and Byrne (2014), who also included papers in German and Japanese. According to Petticrew (2001), several features differentiate good-quality systematic reviews from traditional narrative reviews. The former start with clear question or hypothesis, aim to locate all relevant studies to limit the selection bias, provide explicit descriptions of criteria for the inclusion or exclusion of papers, analyse the quality of the study (the quality of research methodology), and base their conclusions on studies that are methodologically sound.

In our case, a Scopus search was performed based on combinations of key words in 'Title, abstract and key words' on 4 February 2016 and included articles, review papers and articles in press published in English prior to 31 December 2015 in Mediterranean countries, based on the affiliation of the first author. We used the following key words: 'urban forest"'; 'urban woodland'; 'green space'; 'peri-urban forest'; 'urban tree'; 'urban green area'; 'green infrastructure'; 'urban landscape'; 'urban park'; 'historical park'; 'urban ecology'; 'green space branding' and combinations of words 'urban forest'; 'green space'; 'green infrastructure' with the words 'policy'; 'governance'; 'management'; 'climate change'; 'benefit'; 'urban ecosystem service'. Those were discussed and agreed upon by experts participating in the UN FAO's Silva Mediterranea working group on urban and peri-urban forestry in 2015 during their regular twice-a-year meetings. The search retrieved in total 1107 papers covering the period between 1984 and 2015. Only two papers had been published before 1996 (one in 1985 and one in

\footnotetext{
${ }^{1}$ Measured as GDP per capita in PPP.

${ }^{2}$ Measured as the share of GDP.
} 
Table 1

A synthetic profile of Mediterranean countries.

\begin{tabular}{|c|c|c|c|c|c|c|c|c|}
\hline Country & & $\begin{array}{l}\text { Population } \mathrm{x} \\
1000 \text { (1) }\end{array}$ & $\begin{array}{l}\text { Population median } \\
\text { age (2) }\end{array}$ & $\begin{array}{l}\text { Net migration } \\
\text { rate/1000 (3) }\end{array}$ & $\begin{array}{l}\text { Population density } \\
\mathrm{P} / \mathrm{Km}^{2} \text { (4) }\end{array}$ & Urbanization (5) & $\begin{array}{l}\text { GPD/capita } \\
\text { USD (6) }\end{array}$ & $\begin{array}{l}\text { R\&D exp. } \\
\text { (7) }\end{array}$ \\
\hline Northern & Portugal & 10325 & 43,9 & $-2,7$ & 112,7 & 63,5 & 19813 & 1,28 \\
\hline \multirow{13}{*}{ Mediterranean } & Spain & 46444 & 43,2 & $-2,4$ & 92,8 & 79,6 & 26528 & 1,22 \\
\hline & France & 66896 & 41,2 & 1,1 & 122,2 & 79,5 & 36855 & 2,23 \\
\hline & Italy & 60601 & 45,9 & 0,9 & 206,0 & 69,0 & 30527 & 1,33 \\
\hline & Malta & 437 & 40,9 & 4,5 & 1365,5 & 95,4 & 25058 & 0,77 \\
\hline & Slovenia & 2065 & 43,0 & 1,6 & 102,5 & 49,7 & 21305 & 2,21 \\
\hline & Croatia & 4171 & 42,6 & $-1,5$ & 74,5 & 59,0 & 12091 & 0,85 \\
\hline & $\begin{array}{l}\text { Bosnia and } \\
\text { Herzegovina }\end{array}$ & 3517 & 41,0 & $-8,9$ & 68,7 & 39,8 & 4709 & 0,22 \\
\hline & Serbia & 7057 & 40,0 & $-2,2$ & 80,7 & 55,6 & 5348 & 0,87 \\
\hline & Montenegro & 623 & 37,7 & $-1,0$ & 46,3 & 64,0 & 5237 & 0,44 \\
\hline & FYR Macedonia & 2081 & 37,4 & $-0,9$ & 82,5 & 57,1 & 4147 & N/A \\
\hline & Albania & 2876 & 36,2 & $-6,4$ & 105,0 & 57,4 & 9474 & 0,49 \\
\hline & Romania & 19705 & 41,3 & $-3,0$ & 85,6 & 54,6 & 7351 & 0,96 \\
\hline & Bulgaria & 7128 & 43,5 & $-0,7$ & 65,7 & 73,9 & 18104 & 0,96 \\
\hline \multirow[t]{9}{*}{ Eastern Mediterranean } & Greece & 10747 & 43,3 & $-2,9$ & 83,4 & 78,0 & 23324 & 0,46 \\
\hline & Cyprus & 1170 & 34,9 & 4,0 & 126,6 & 66,9 & 10788 & N/A \\
\hline & Turkey & 79512 & 29,9 & 4,3 & 103,3 & 73,4 & 7914 & N/A \\
\hline & Lebanon & 6007 & 28,5 & 49,1 & 587,2 & 87,8 & . & $\mathrm{N} / \mathrm{A}$ \\
\hline & Syria & 18430 & 20,2 & $-41,8$ & 100,4 & 57,7 & 37293 & 4,27 \\
\hline & Israel & 8547 & 30,2 & 0,5 & 395,0 & 92,1 & 4088 & N/A \\
\hline & Jordan & 9456 & 22,2 & 23,9 & 106,5 & 83,7 & 3514 & 0,72 \\
\hline & Egypt & 95689 & 24,7 & $-0,6$ & 96,1 & 43,1 & . & N/A \\
\hline & Libya & 6293 & 27,2 & $-14,0$ & 3,6 & 78,6 & 3689 & 0,63 \\
\hline \multirow{3}{*}{$\begin{array}{l}\text { Southern } \\
\text { Mediterranean }\end{array}$} & Tunisia & 11403 & 31,1 & $-1,2$ & 73,4 & 66,8 & 3844 & N/A \\
\hline & Algeria & 40606 & 27,5 & $-0,8$ & 17,0 & 70,7 & 2832 & N/A \\
\hline & Morocco & 35277 & 27,9 & $-1,8$ & 79,0 & 60,2 & 19813 & N/A \\
\hline
\end{tabular}

(1) The World Bank. World Development Indicators. Population, total, 2016.

(2) UN World Population Prospects 2017. Median age of the total population (years) for 2015.

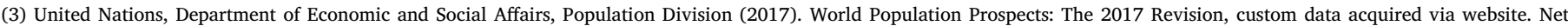
migration rate (per 1000 population) for 2010-2015.

(4) The World Bank. World Development Indicators. Population density P/Km² 2016.

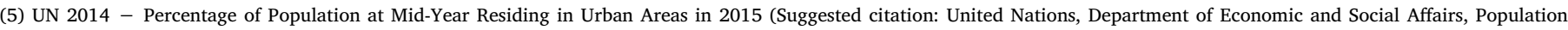
Division (2014). World Urbanization Prospects: The 2014 Revision, CD-ROM Edition).

(6) World Bank national accounts data, and OECD National Accounts data files. GDP per capita (current US\$) for 2016.

(7) United Nations Educational, Scientific, and Cultural Organization (UNESCO) Institute for Statistics. Research and development expenditure (\% of GDP) for 2015.

N.B. There are different division of the Mediterranean region, but for the purpose of this paper 26 countries were taken into consideration.

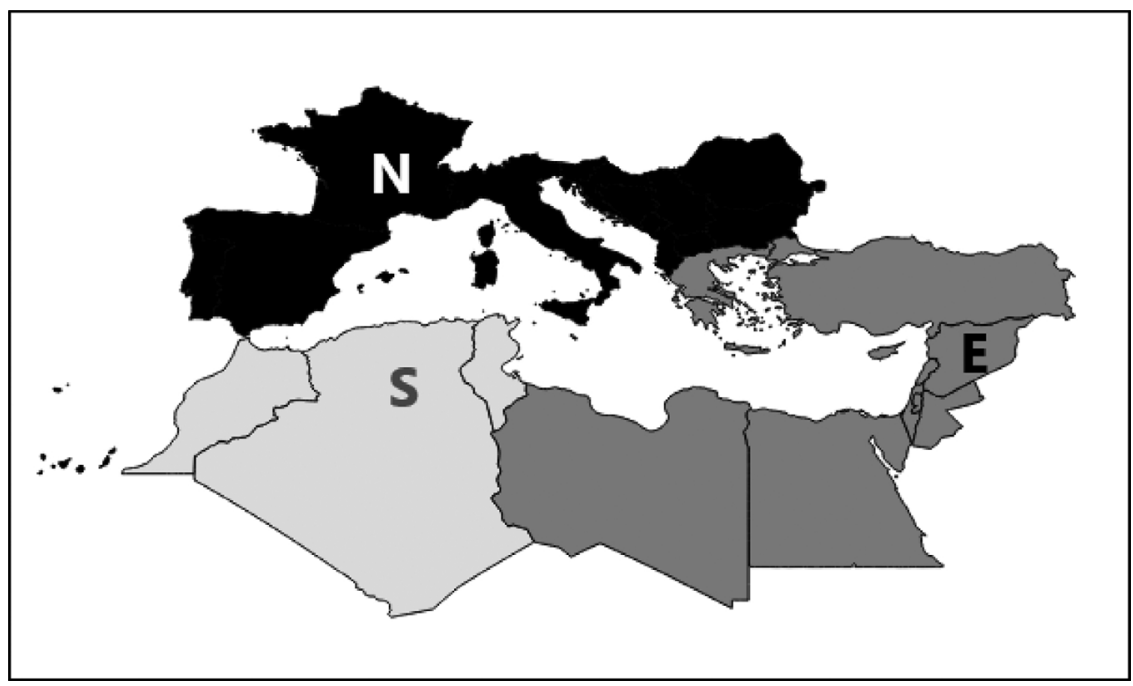

Fig. 1. Mediterranean countries by sub-regions $(\mathrm{N}=$ Northern, $\mathrm{E}=$ Eastern, $\mathrm{S}=$ Southern $)$.

1995). Therefore; we decided to take into consideration only the period of the past 20 years (from 1996 to 2015). Full papers were downloaded when possible. In cases when it was not possible to retrieve full papers from Scopus; titles of those papers were googled and downloaded from other publication databases including personal profiles of researchers from social networking sites for researchers such as ResearchGate and
Academia.edu. In some cases when it was not possible to access full papers; only abstracts were used in further analysis. Before the analysis; papers were selected based on several criteria. Only papers dealing with trees or other woody vegetation in urban and peri-urban areas were included into further analysis. Duplicate papers papers; papers whose first authors were not affiliated with institution(s) in Mediterranean 
countries; papers that did not fall into category of research papers; review papers and articles in press; as well as those with all case studies or research sites outside the Mediterranean were excluded. Also; papers that were only vaguely connected with trees for example; when research was located in an urban park; but the focus was on birds were also excluded. An exception to this rule was made; for instance; when authors discussed the relation between urban forest or park structure or management and distribution of birds or other animals or gave recommendations on how to manage urban parks to keep urban biodiversity. The final database included 408 papers that were further analysed (the list is provided in the Supplementary material 1). The Excel database comprised data on paper's full reference; year of publication; country of the first author; journal in which the paper was published; the topic of the paper; research location; method(s) applied and research strategy/approach. Similar topics were further grouped into broader research themes.

\section{Results}

\subsection{Distribution of papers over time and based on the affiliation of the first} author

The distribution of papers between 1996 and 2015 showed a continuous increase over the last 10 years (Fig. 2). A similar distribution occurred in the top five productive countries (Fig. 4).

The number of publications per country varied significantly from one in Algeria, Jordan and Tunisia to 106 in Italy. The results show that some Mediterranean countries such as Italy, Turkey and Spain, whose researchers produced about two thirds of all papers published in the given period, are forerunners in urban forest research. At the other end of the spectrum, publications in some countries are limited or non-existent (Fig. 3). Out of the 26 Mediterranean countries taken into consideration, 16 had at least one publication in the past 20 years, but 10 countries had none whatsoever (Albania, Bosnia and Herzegovina, Cyprus, Lebanon, Libya, the Former Yugoslav Republic of Macedonia, Malta, Montenegro, Morocco and Syria).

\subsection{Research themes}

Papers were grouped into 19 broad themes. The overall distribution of research themes in the Mediterranean, based on the number of papers, revealed that some themes were more favoured by researchers than others (Fig. 5). The results also showed that not all themes were present in all countries, while some prevailed in only one country receiving marginal interest in the others.

The most frequent papers are those addressing green space in the context of different types of pollution (in total 49 papers). Air pollution was the most prevalent theme (41 papers). Soil pollution was less explored (in eight papers, in three of which it was addressed together with air pollution). Noise and light pollution were covered in one paper each respectively. Looking at the type of pollutants investigated, about one third of papers dealt with heavy metals, while polycyclic aromatic hydrocarbons, particulate matter and ozone received less attention. Some tree species, such as Quercus ilex L., Tilia ssp., Cercis siliquastrum L., Nerium oleander L., Fraxinus excelsior L., Acer negundo L., were analysed in the context of their actual or potential usefulness to act as biomonitors or bioaccummulators of certain pollutants. Italian researchers published about half of the papers in this thematic group, while the other half was distributed among nine other countries (Turkey, Greece, Spain, Serbia, Bulgaria, Romania, Egypt, Israel and Portugal).

The next most frequent theme ( $\mathrm{N}=39$ papers) explored connections between green space and various aspects of human health, for instance the correlation between proximity to green space and cardiovascular diseases, physical and psychological well-being, healthy lifestyles, pregnancy and birth outcomes, or discussed potential allergenicity of tree species. Studies related to psychological well-being, allergies, pregnancy and birth outcomes, and healthy lifestyle were almost equally distributed and accounted for two thirds of the analysed papers. The theme was most prominent in Spain, while only up to four papers were published in Bulgaria, France, Italy, Turkey, Portugal, Romania and Slovenia in the given period.

Sociocultural values and urban biodiversity themes came in third, with 37 papers each. Sociocultural papers addressed mainly human perceptions, attitudes, behaviour, use, preferences and beliefs with regard to urban green space, while biodiversity papers mostly included papers on inventory of urban flora and fauna, and the relation between green space and animal or micromycetes diversity. The majority of papers addressed perception, behaviour and preferences, while attitudes, beliefs and satisfaction with green space were the topic of interest only in one paper each. However, papers on human thermal perception were grouped under the theme 'green space and climate regulation', while papers on the perception of biodiversity were counted as 'urban biodiversity' papers. More than a half of the papers dealing with sociocultural values were produced in single country $(\mathrm{N}=21)$, Turkey, while up to five papers were published in Italy, Slovenia, Spain, Romania, Croatia, France and Portugal.

The biodiversity papers focused on the inventory of urban flora and fauna, and the relation between green space and animal or micromycetes diversity. Animal biodiversity was a topic in almost half of the papers (17 out of 37 ) in the urban biodiversity group, with the majority of papers dealing with the relation between green space and bird populations (11 papers), while carabid beetles, small mammals, ants, herpetofauna and arthropod communities were covered in one or two

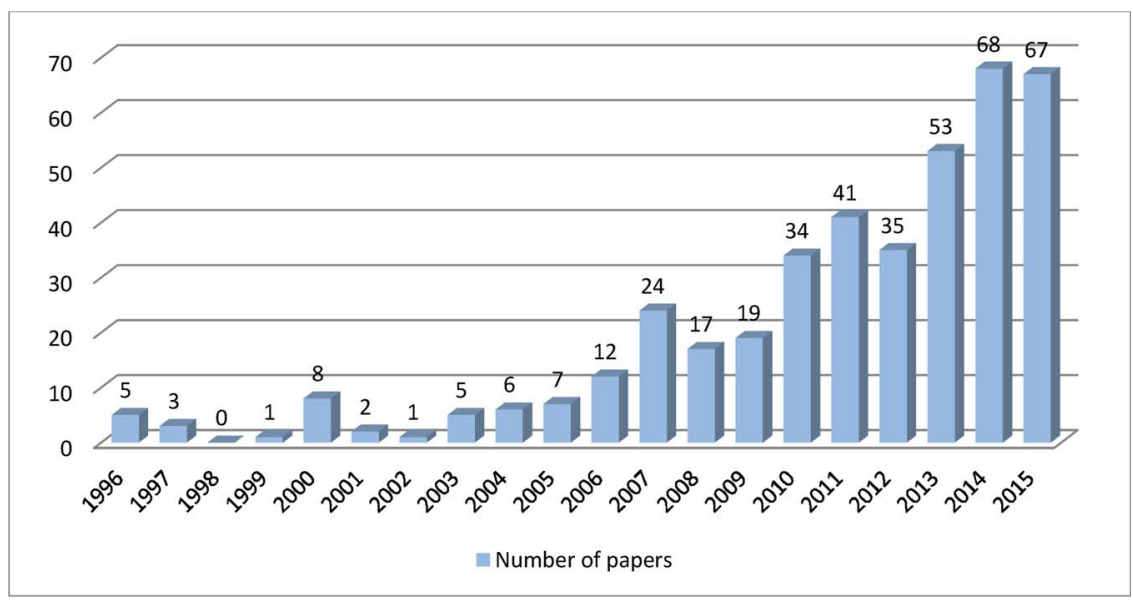

Fig. 2. Distribution of papers per year (1996-2015), N = 408 . 


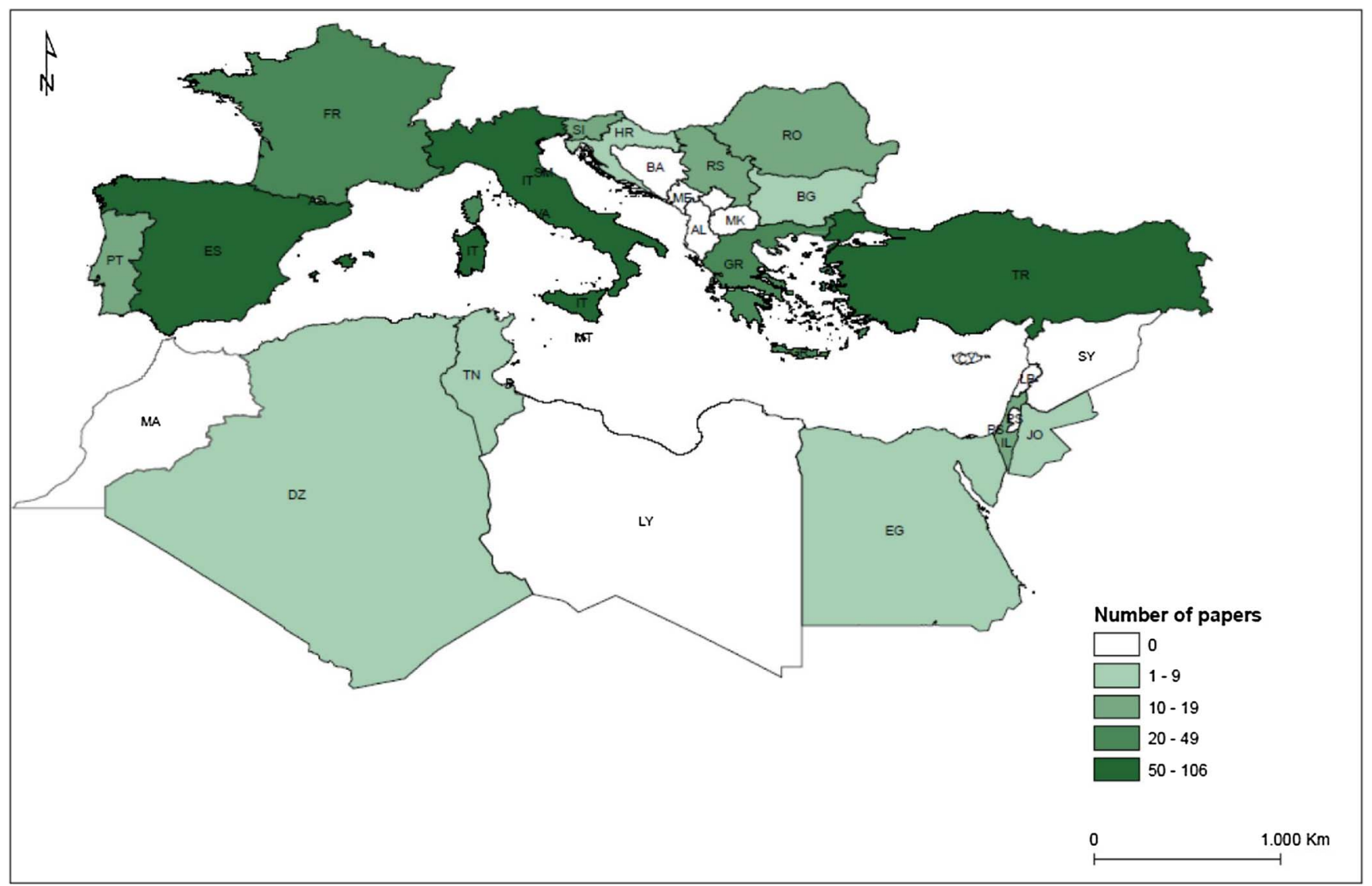

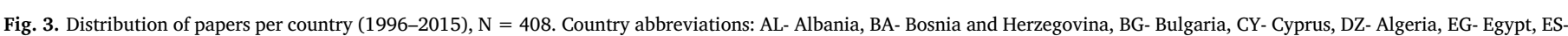

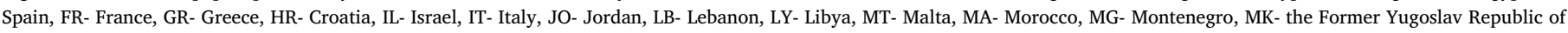
Macedonia, PT- Portugal, RO- Romania, RS- Serbia, SI- Slovenia, SY- Syria, TN- Tunisia, TR- Turkey.

papers each. Plant biodiversity was second with about one third of papers (13 out of 37). Urban biodiversity papers were found for seven countries (mainly France, Turkey, Spain, Greece and Italy with only two papers in each Israel and Portugal).

Papers focusing on different aspects of green space management were the fourth most frequent $(\mathrm{N}=36)$. In this group we included papers dealing with tree health assessment with or without using decision support systems and devices (e.g. tree decay detection) for better green space management, the selection of trees for planting, tree growing, tree pruning or risk assessment for tree climbers, and green space quality assessment. Similar to themes of human health and sociocultural values, this theme was also most prominent in one country in comparison to others, in this case Italy, whose researchers published more than half of the papers in the given period $(\mathrm{N}=20)$. Other countries included Turkey, Greece, Spain, Serbia, France, Israel, Romania and Slovenia with up to four papers each.

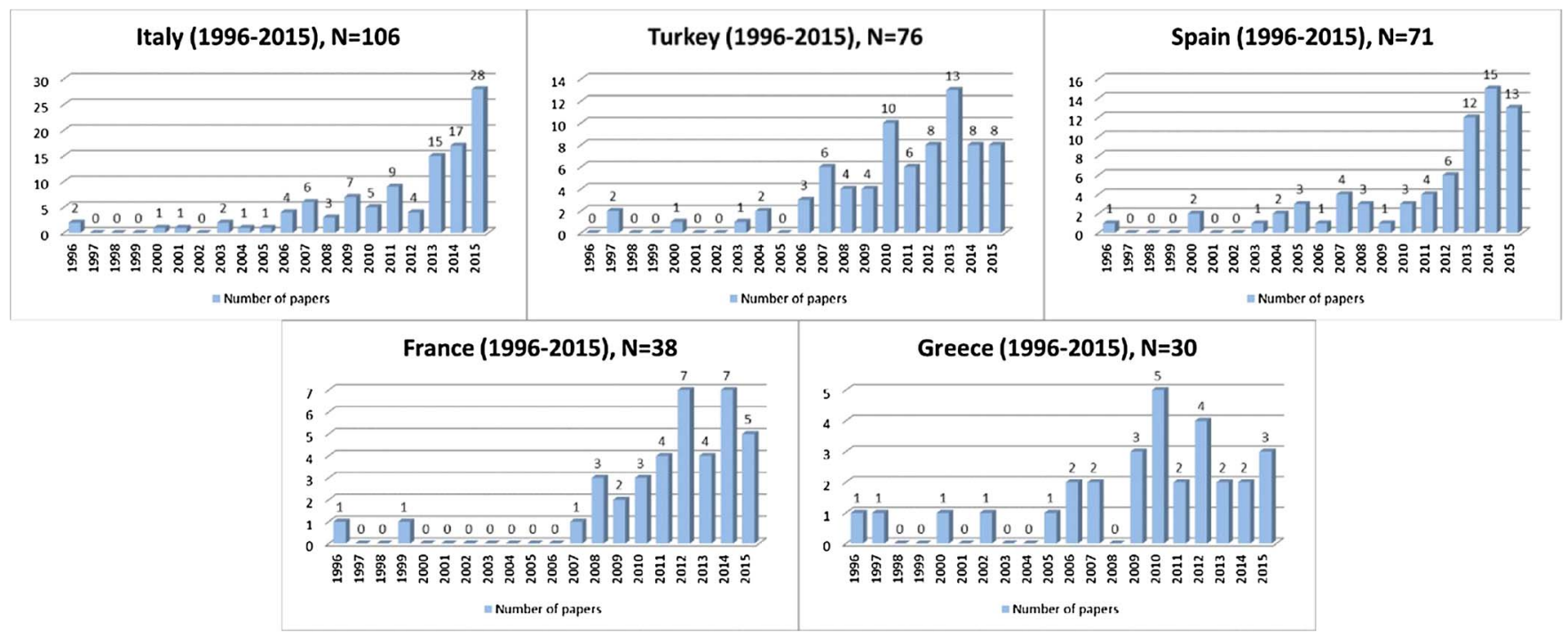

Fig. 4. Distribution of papers over time for the top five most productive countries. 


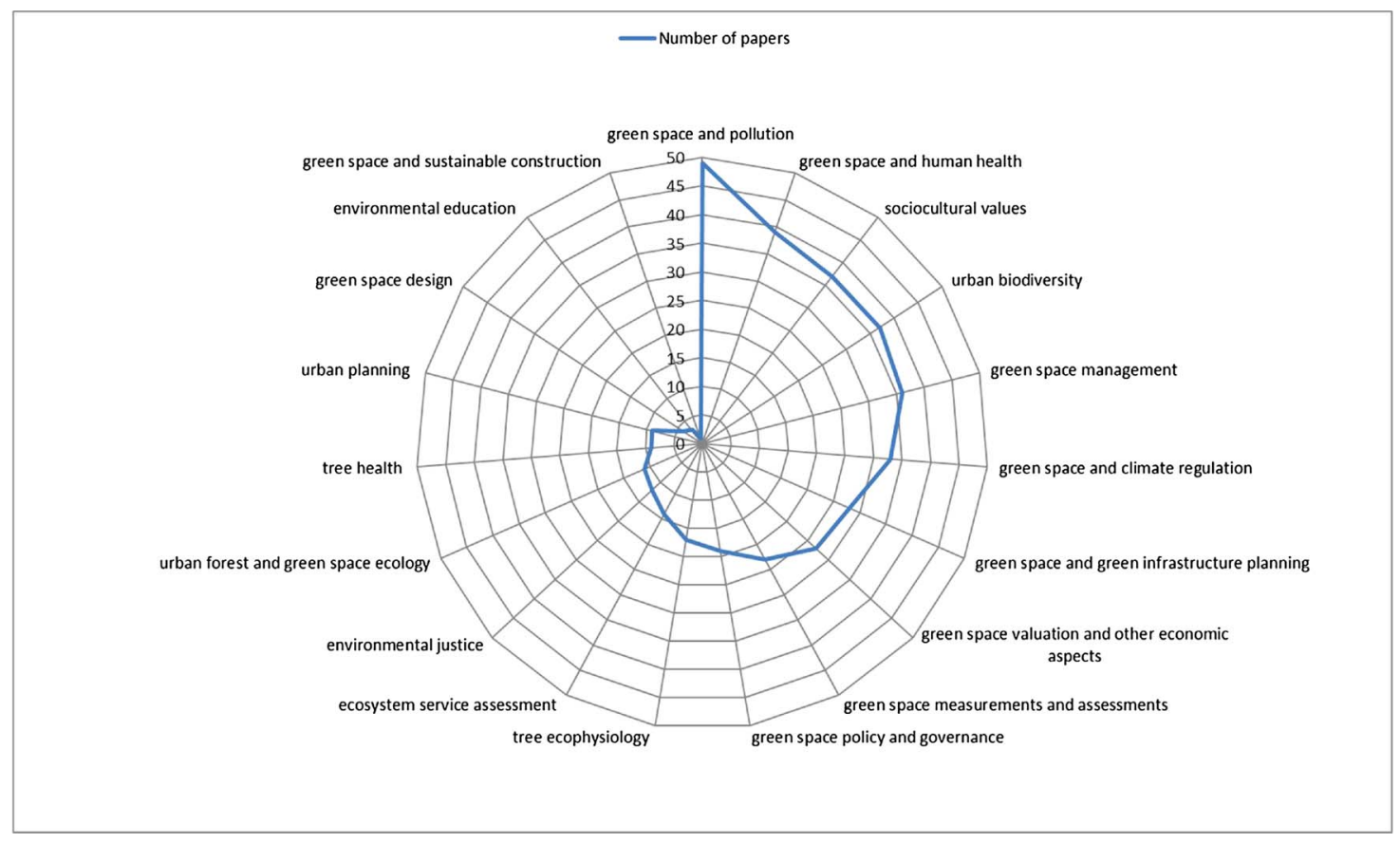

Fig. 5. Distribution of urban forest related papers per research themes across the Mediterranean ( $N=408$ papers).

Papers dealing with green space in the context of climate regulation $(\mathrm{N}=33)$ were present in 11 countries with researchers in Greece $(\mathrm{N}=9)$ and Israel $(\mathrm{N}=6)$ being most productive and publishing about half of the papers. The other half was distributed among Turkey, Portugal, Egypt, Italy, Spain, Algeria, Romania and Slovenia. About two thirds of papers covered topics of urban forests in the context of human thermal comfort and urban heat island effect.

Green space and green infrastructure planning $(\mathrm{N}=28)$ mostly caught the interest of researchers in Turkey and Italy, while the other half of the papers was distributed among Portugal, France, Slovenia, Spain, Egypt, Greece, Romania and Serbia with up to three papers in each country. In the case of green space valuation and other economic aspects $(\mathrm{N}=27)$, most papers were published by Spanish authors ( $\mathrm{N}=11$ ), followed by authors from Turkey, France and Italy in Greece, in addition to Israel and Portugal with only one publication each. The theme covered various topics, addressing calculations of green space benefits, such as the effect of green space on house prices, recreational value, willingness to pay for green space conservation, classifying and valuing ecosystem services for urban planning, etc.

The group of papers labelled 'green space measurements and assessments' $(\mathrm{N}=23)$ dealt with tree and urban forest inventories, assessment of crown volumes, woody biomass after pruning, tree growth estimations, tree root analysis or even measurement of wood formation in urban trees. This theme was prevalent in Spain $(\mathrm{N}=8)$ and Italy $(\mathrm{N}=6)$ and only sporadically present in France, Slovenia, Turkey, Bulgaria, Greece and Romania with no more than two papers in each country.

In comparison to these themes, some caught even less interest with less than a publication per year in the analysed period, e.g. less than 20 papers between 1996 and 2015 (Fig. 4). These include papers dealing with green space policy and governance $(\mathrm{N}=19)$, tree ecophysiology $(\mathrm{N}=17)$, ecosystem service assessment $(\mathrm{N}=14)$, environmental justice $(\mathrm{N}=12)$, and urban forest and green space ecology $(\mathrm{n}=11)$. Policy and governance theme was investigated mostly by researchers from France $(\mathrm{N}=5)$ and Serbia $(\mathrm{N}=4)$, while only up to two papers each were written by researchers from Croatia, Greece, Israel, Italy, Spain and Turkey. Tree ecophysiology $(\mathrm{N}=17)$ covered tree response to external, usually negative effects, such as drought, ozone or salt, and mostly caught the interest of researchers in Italy $(\mathrm{N}=12)$, while up to two papers per country were found in Spain, Greece, Tunisia and Turkey. Ecosystem service assessment $(\mathrm{N}=14)$ papers mainly dealt with carbon sink, sequestration and offset $(\mathrm{N}=7)$, and the quality of soundscape and noise attenuation $(\mathrm{N}=5)$. The theme prevailed in Italy $(\mathrm{N}=10)$, with only two papers in each Spain and Turkey. Environmental justice $(\mathrm{N}=12)$ in this analysis referred to papers dealing mostly with access to green space $(\mathrm{N}=8)$ and were present in six countries (Turkey, Israel, Romania, France, Italy and Spain). Other topics included access to biodiversity, distributional justice and inclusive public places.

Finally, there were less than 10 papers associated to the themes of tree health and urban planning $(\mathrm{N}=9$ each). The former was present in Italy, Greece and Spain, while the latter in six countries (Turkey, Romania, Jordan, Portugal, France, Italy and Romania). Other themes included green space design ( $\mathrm{N}=4$ in Egypt, Turkey and Italy), environmental education ( $\mathrm{N}=3$ in Croatia, Greece and Romania), and green space and sustainable construction ( $\mathrm{N}=1$ in Italy).

Distribution of themes per country showed that some countries exhibited some sort of research specialisation (Fig. 6). For instance, studies related to various types of pollution, mostly air pollution, as well as studies dealing with different aspects of green space management, ecophysiology and ecosystem services assessment were most frequent in Italy. The same went for studies related to sociocultural values in Turkey, connection between green space and human health, as well as green space valuation and other economic aspects in Spain, urban biodiversity in France or the role of green space in climate regulation in Greece. No such specialisation was evident for other themes due to the small(er) total number of publications per country and the distribution of papers on many themes.

The number of countries in which certain themes were present also differed. For instance, climate regulation was covered by researchers in eleven countries; pollution and green infrastructure planning in ten; green space management in nine; human health, sociocultural values, measurements and assessments, as well as policy and governance in eight; biodiversity, valuation and other economic aspects in seven; environmental justice and urban planning in six; ecophysiology and tree health in five; urban forest and green space ecology in four; ecosystem service assessment, green space design and environmental education in three; while green space in the context of sustainable 

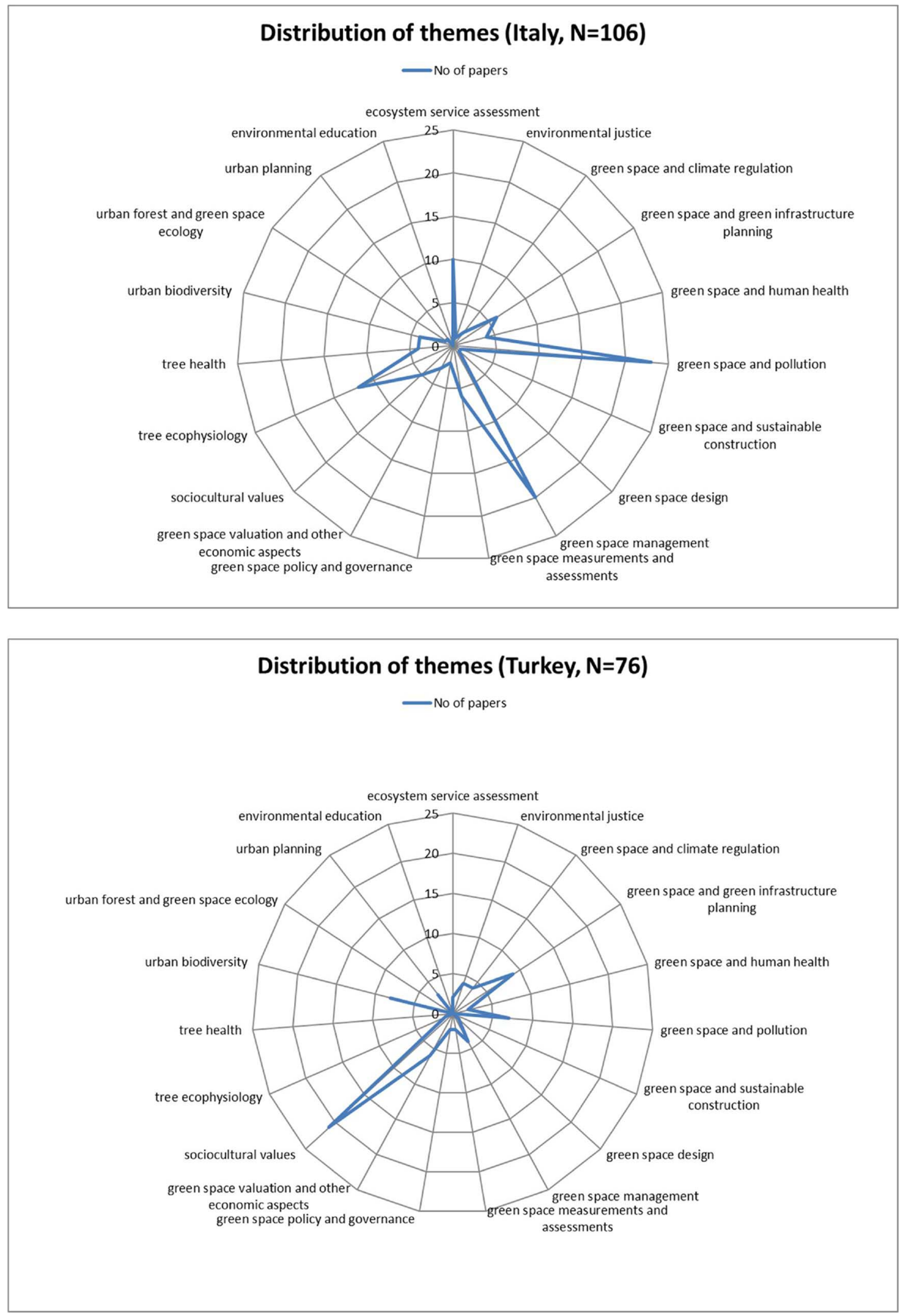

Fig. 6. Distribution of themes per country for top five countries based on the number of publications. 

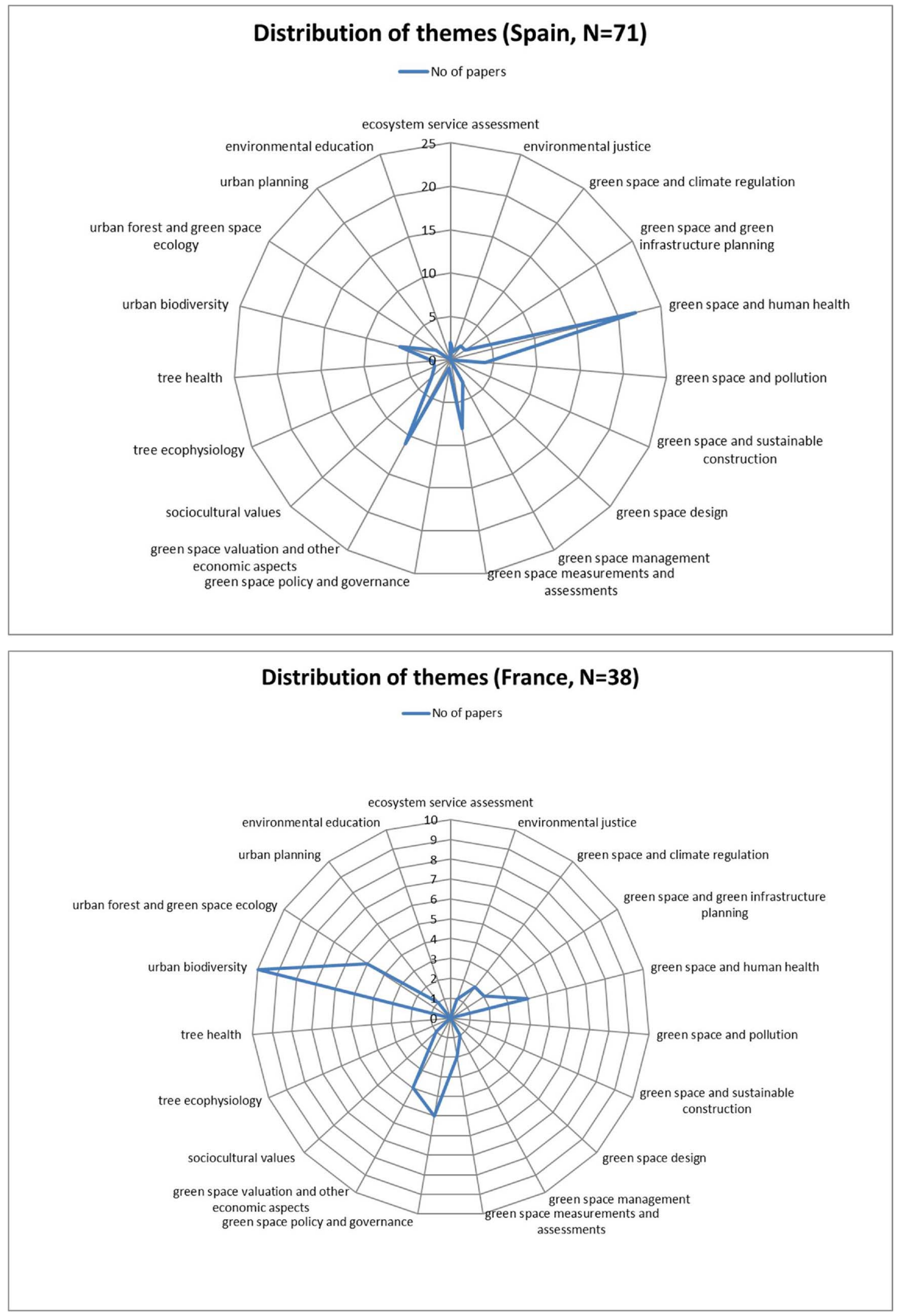

Fig. 6. (continued) 


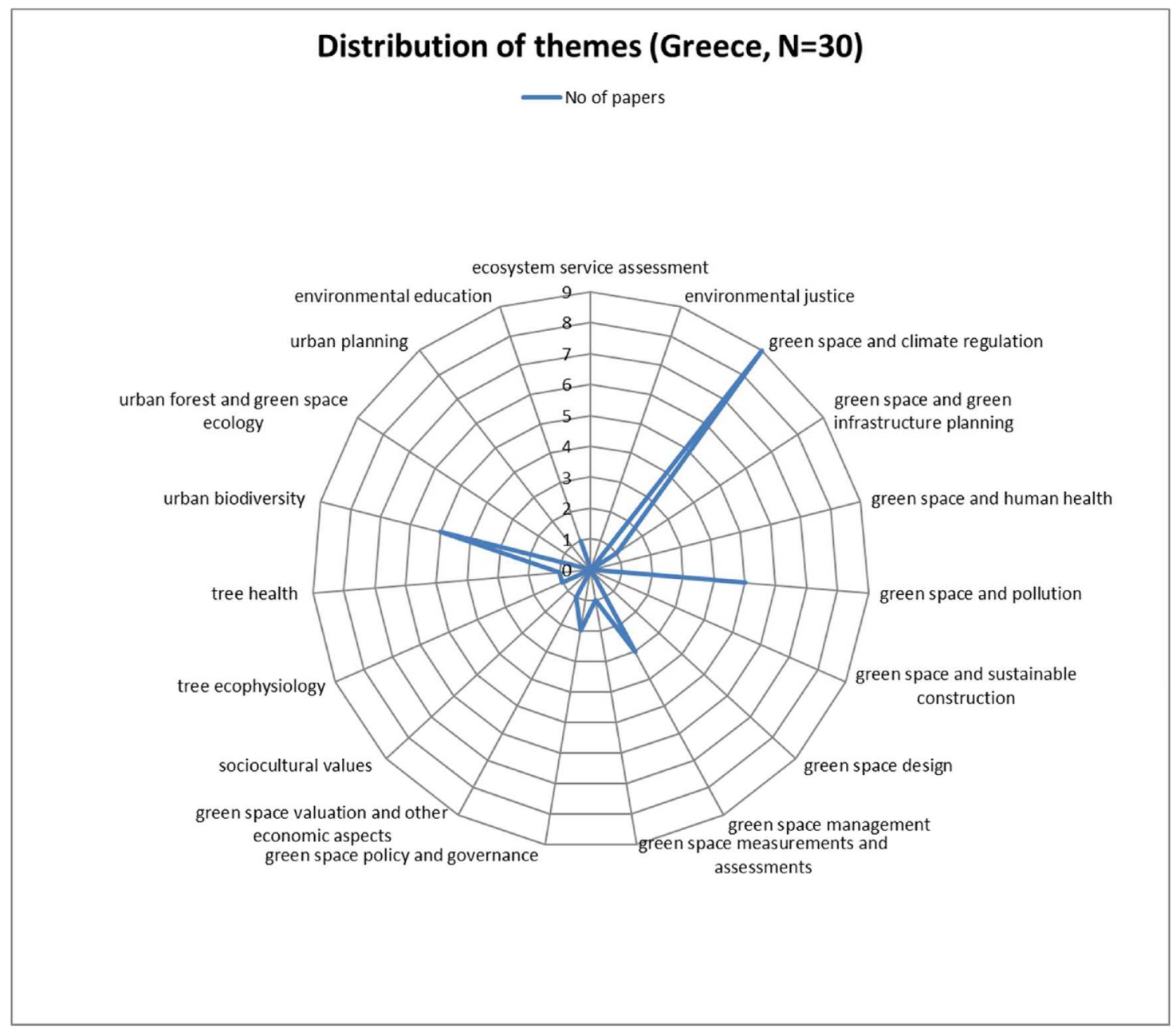

Fig. 6. (continued)

Table 2

Research methods used in analysed papers.

\begin{tabular}{ll}
\hline Method & Number of papers \\
\hline Field measurements & 107 \\
Survey questionnaire & 82 \\
Spatial analysis (Geographic Information System - GIS, & 63 \\
$\quad$ remote sensing) & 59 \\
Field sampling and/or laboratory analysis & 35 \\
Modelling/simulation/scenario & 33 \\
Descriptive or no method reported & 32 \\
Experiment (field, nursery, laboratory) & 25 \\
Literature analysis & 21 \\
Field observations and assessments & 14 \\
Other & 11 \\
Secondary data analysis (existing database \& record & \\
$\quad$ analysis) & 9 \\
Interviews & 4 \\
Focus groups & \\
\hline
\end{tabular}

construction was present in only one country.

\subsection{Research methods and approaches}

A wide range of methods was applied in the analysed papers (Table 2). The majority of studies used a single method, while only 114 papers reported multiple methods. About one quarter of the studies included field measurements $(26.2 \%)$. Survey questionnaire (mail, telephone, face-to-face) was a method of choice in one fifth of the papers (20.1\%), mainly those addressing human perceptions, attitudes and behaviour. In studies employing spatial analyses (15.4\%), remote sensing and GIS were often included. Other reported methods (data modelling, experiment, literature analysis, field observations and assessments, secondary data analysis, interviews, focus groups and other) were present each in less than $10 \%$ of the papers. Some papers applied descriptive methods and in some papers authors did not report the method at all (8.1\% of papers). Modelling was applied to analyse both the collected and secondary data.

Nearly all studies adopted quantitative research strategies (326 out of 375 or $86.9 \%$ ), with only a few studies applying qualitative (37 out of 375 or $9.9 \%$ ) or mixed-method strategies (12 out of 375 or $3.2 \%$ ).

\subsection{Study location}

Altogether, 167 different study locations were reported across the Mediterranean in the papers (Supplementary material 2). In 55 papers the location was not specified. About three quarters of studies took place in a single location (city or region) (312 out of 408 papers), while only a small number of studies were performed on multiple sites (55 out of 408). When looking at the number of locations per country, the highest number is found in Spain (37) and Italy (36), and somewhat less in Turkey (23), France (19), Romania (12) and Greece (11). A small number of locations was found in Egypt and Israel (6 locations each), Portugal (5), Bulgaria (4), Croatia and Slovenia (2 locations each), with only one location in Albania, Bosnia and Herzegovina, Jordan and Serbia. Expectedly, capitals were used more frequently as study locations than other cities. However, in the most productive countries there was indication of several research groups existing outside capital cities. 
For instance, Rome is a study location in majority of Italian papers, but there was also significant research done in Milan and Bari (Supplementary material 2).

\section{Discussion and conclusions}

According to our analysis, the distribution of publications across the Mediterranean varied, with some countries and regions being more prolific than others (Fig. 3). Urban forest research production in the analysed period was almost exclusively concentrated in the Northern (about two thirds of the papers) and the Eastern Mediterranean countries (about one third), with only two papers from Southern Mediterranean countries (Fig. 3). In 10 countries, mostly Western Balkan and Eastern Mediterranean countries, there were no urban forest-related publications whatsoever.

The reasons for the uneven distribution of publications across the Mediterranean could be various. This could be due to civil unrest since many of these countries experienced armed conflicts (e.g. in Algeria, Bosnia and Herzegovina, Croatia, Egypt, FYR Macedonia, Israel, Libya, Serbia, Syria) in the analysed period (UNEP/MAP, 2016). Certainly, one of the reasons would be the different number of active researchers and/ or research groups working on urban forest-related topics in each country, as well as their distribution across the Mediterranean, a claim that we were not able to either confirm or discard without conducting scientific network analysis based on the selected papers. However, this was not one of the aims of this review. Another possible reason was the fact that we took into account only papers in English. A bibliometric analysis of Scopus in the 1996-2011 period showed a strong English language bias, with about $80 \%$ of journals indexed in Scopus being published in English, while the others needed to have at least the abstract in English to be included in the database (van Weijen, 2012). The same study investigated language preferences of research communities in several countries (including Italy, France and Spain) both in general and across disciplines. The results showed stronger and increasing preference of Italian researchers for publishing in English, in comparison to researchers in France and Spain where the preference was much lower and remained stable over time. However, preferences for publishing in local language in these countries were much stronger in health sciences, social sciences, arts and humanities, in comparison to life sciences. Based on research disciplines we conclude that preference for English papers in our analysis probably did not have a big impact on the final distribution of papers for Italy, France and Spain. Unfortunately, the study did not include other Mediterranean countries. When looking at our top five most productive countries (Italy, Turkey, Spain, France and Greece), all of these, with exception of Greece, are among the top 20 countries based on the number of publications in all fields (Thomson Reuters, 2012).

However, the increase in the number of publications in the past 10 years was evident in all countries (Fig. 3). In general, the urban forestry concept emerged in Europe in the early 1980s, first in the UK, followed by Ireland and the Netherlands, and later by Nordic countries (Randrup et al., 2005; Konijnendijk et al., 2006), but it took until the early 1990s before the concept found broader acceptance (Konijnendijk, 2003). However, Mediterranean countries were not specifically discussed in these historical reviews. Our analysis showed that urban forest research in Mediterranean countries in general is indeed somewhat lagging behind the European urban forestry pioneering countries. However, there have been some recent efforts contributing to the promotion of urban and peri-urban forestry in the Mediterranean targeting researchers, practitioners and policy makers. During the workshop 'MED-ways: guidelines and common routes for the future challenges of urban and peri-urban forests in Mediterranean cities' that took place in Florence (Italy) in 2011 it was evident that there was a need for a regional partnership to address urban and peri-urban forestry issues in the Mediterranean through networking among countries. It did not take long for the UN FAO's Committee on Mediterranean Forestry Questions (i.e. Silva Mediterranea), to establish the working group on urban and peri-urban forestry in 2012 (FAO, 2017). Most recently, in 2017, the European Forum on Urban Forestry, an annual event that brings together researchers and professionals from around the world, took place in Barcelona (Spain). However, the impact of these efforts on urban forestry and urban forest research in the region will have to be evaluated in the future.

When looking at the distribution of themes it was evident that some themes have been more relevant in comparison to others, both in general and per country (Figs. 5 and 6). The theme of green space and various types of pollution was ranked as first based on the number of papers, and was most relevant in Italy (Figs. 5 and 6). The problem of air pollution has generally been acknowledged as a problem for human and the health of ecosystems in Mediterranean urban areas (Manes et al., 2008; Paoletti, 2009; Sgrigna et al., 2015; EEA, 2016; UNEP/ MAP, 2016).

Despite the global popularity of the Mediterranean diet, health problems of the human population in the Mediterranean are increasingly aligned with global trends. For instance, the increase in noncommunicable diseases (cardiovascular diseases, cancers, respiratory diseases and diabetes), a main cause of premature death globally, has led to the loss of 2.2 million lives per year, i.e. $57 \%$ of the mortality (WHO, 2017), in Eastern Mediterranean countries alone. Therefore, it is not a surprise that the relation between green space and human health was ranked highly in this review, even though being mainly of interest for researchers from Spain.

Themes of sociocultural values and urban biodiversity were both equally relevant (Fig. 4), even though the number of publications per theme is rather low, with less than two publications per year in the 20year period under review. The former was mostly relevant for researchers in Turkey, while the latter showed no specialisation regarding country. Overall, both themes were relevant only for a number of countries. The focus on people, their experience and relationship with nature in urban areas was identified as increasingly important (Sreetheran and Konijnendijk van den Bosch, 2014; Krajter Ostoić and Konijnendijk van den Bosch, 2015; Kabisch et al., 2015; Krajter Ostoić et al., 2017; O’Brien et al., 2017), especially in highly urbanised areas such as the Mediterranean. However, studies addressing cultural differences with regard to perceptions, attitudes, behaviours or use of urban forests and green space were missing in our review. The Mediterranean basin is considered as the world's third richest biodiversity hotspot based on its plant biodiversity (Mittermeir et al., 2004), hence research interest in biodiversity was expected. However, our analysis included only studies related to urban areas that to some extent may explain a somewhat low number of papers dealing with the issue.

Besides being a biodiversity hotspot, the Mediterranean region is also considered a climate change hotspot (Diffenbaugh and Giorgi, 2012; EEA, 2015). Still, papers dealing with urban forests in the context of climate regulation were only the sixth most frequent based on our sample with less than two papers annually in the analysed period (Fig. 5). The reasons could be that climate change is ranked low on the political agenda in Mediterranean countries or that there is limited awareness of how urban green space can contribute to climate adaptation and mitigation in urban areas despite being promoted in literature, policies and practice (Kazmierczak and Carter, 2010; EC, 2013a, b; Hiemstra et al., 2017). According to the European Climate Adaptation Platform, almost all EU Mediterranean countries either have or are developing national climate change adaptation strategies and/or action plans. However, an analysis of several European urban climate adaptation plans at the city level (including those for the cities of Barcelona, Milan, Paris, Rome and Venice) showed that ecosystem/nature-based adaptation measures are recognised, but their actual implementation is not secured (Geneletti and Zardo, 2016).

Green infrastructure is a rather new concept in European spatial planning policy, but highly promoted by European Commission as a mean for climate change adaptation and biodiversity protection, among 
other things (EC, 2011; EC, 2013a, b). As it is considered to be an emerging topic in the context of urban forest research (Krajter Ostoić and Konijnendijk van den Bosch, 2015), the scarcity of papers addressing it in this review was not surprising. The same applies to the theme of urban forests and green space in the context of urban planning that received only marginal interest in the analysed timeframe (Fig. 5).

The somewhat low number of papers related to policy and governance is not surprising due to the low presence of papers addressing these topics in general and the fact that it has only recently caught the attention of the scientific community (Bentsen et al., 2010; Lawrence et al., 2013; Krajter Ostoić and Konijnendijk van den Bosch, 2015). As a response to this evident research gap, European Commission's Seventh Framework Programme project 'Green Surge' has been focusing more on these issues, but reports covered only examples from some European Mediterranean countries (namely Italy, Portugal, Romania, Slovenia) (Buizer et al., 2015; Buijs et al., 2016; Ambrose-Oji et al., 2017).

Research on green space valuation has been so far more common in some continents and countries, such as North America and somewhat Asia, with less interest in Europe and Africa (Roy et al., 2012; Krajter Ostoić et al., 2014; Krajter Ostoić and Konijnendijk van den Bosch, 2015). In Europe, the majority of studies come from the UK and Finland (Krajter Ostoić et al., 2014), while it is less present in Mediterranean countries (Roy et al., 2012; Krajter Ostoić et al., 2014) with the exception of Spain (Morancho, 2003; López-Mosquera and Sánchez, 2011; Baró et al., 2014). For instance, the contribution of Barcelona's urban forests to air purification and climate change mitigation policies was calculated using the i-Tree Eco model (Baró et al., 2014). Monetary valuation of ecosystem services of urban forests and green space is often used as an argument for investment in these resources and to justify spending of the public budget (Rogers et al., 2017). Additionally, studies dealing purely with ecosystem service assessments without monetary valuation were present even though to a lesser extent, and Italian researchers conducted the majority of these.

To conclude, some themes received only marginal attention or were not present at all. These include topics dealing with policy and governance, economic benefits, contribution of urban forests and green space to water and soil management and protection, green space design, urban forests and green space in the context of urban planning, issues of forest fires, food and wood security (FAO, 2016). When compared to some recent Mediterranean forest research reviews (Di Matteo et al., 2015; Nardi et al., 2016), this review shows distinction regarding relevant themes between forest and urban forest researchers. For instance, forest researchers show only marginal interest in urban forestry, while at the same time are more interested in climate change, ecophysiology, and biodiversity (Di Matteo et al., 2015). On the other hand, our results showed less interest in climate change than expected.

Distribution of different research methods and approaches used was dependent on the research discipline on one hand and general prevalence of quantitative research on the other (Krajter Ostoić and Konijnendijk van den Bosch, 2015). The review shows a need to complement quantitative research approach and information with deeper insights that may be provided by qualitative and mixed approaches in future. This is especially relevant for research in sociocultural values that relied almost exclusively on quantitative surveys.

Information on urban forest research is still missing for many countries. Distribution of research locations (Supplementary material 2) indicates that multiple research sites and comparison between these would be useful in the future.

Also, since we did not aim at assessing the quality of urban forest knowledge in Mediterranean countries, the quality of papers was not taken into consideration. However, there is an evident need for such an analysis, particularly in terms of contribution to the implementation of current (e.g. Mediterranean strategy for sustainable development) or future urban forestry policies (e.g. regional guidelines on urban and peri-urban forestry) in the Mediterranean. Additionally, information on collaboration between researchers, institutions and/or countries would be relevant in future since most issues Mediterranean countries are facing are transnational in nature (Nardi et al., 2016). Hence, we consider this review only a first step towards better understanding of urban forest research structure and its evolution in Mediterranean countries.

In the end, some limitations of the study need to be addressed. There is a language bias since we took into consideration only papers in English. By doing it, we possible excluded unknown number of papers written in local languages that may have provided different insights. However, almost all other review studies discussed in the Introduction took the same approach. Also we only used Scopus as a source of publications, but not Web of Science mostly because these two databases largely overlap, and Scopus covers the period we took into consideration (Letina, 2017). In comparison to some other review studies, grey literature was not taken into consideration. In that sense, our review complied with some rules for good quality systematic reviews provided by Petticrew (2001), while the others were not deemed important in this case, for instance, the quality of papers included. Finally, since the review only analysed scientific papers, the result might mainly be of interest for researchers. However, the information presented in Supplementary material 2, which makes it possible to find out what research has been done so far in which particular urban area across the Mediterranean, may be useful for decision-makers and practitioners as well.

\section{Acknowledgements}

We would like to acknowledge all the friends actively participating in the UN FAO's Silva Mediterranea Working Group 7 on Urban and Peri-urban Forestry. They never stopped to encourage and promote this study and we are very grateful for the suggestions and help they gave us during the last meetings of the group.

\section{Appendix A. Supplementary data}

Supplementary data associated with this article can be found, in the online version, at https://doi.org/10.1016/j.ufug.2018.03.005.

\section{References}

Ambrose-Oji, B., Buijs, A., Gerőházi, E., Mattijssen, T., Száraz, L., Van der Jagt, A., Hansen, R., Rall, E., Andersson, E., Kronenberg, J., Rolf, W., 2017. Innovative Governance for Urban Green Infrastructure: A Guide for Practitioners, GREEN SURGE Project Deliverable 6.3. University of Copenhagen, Copenhagen. A vailable at: http:/ greensurge.eu/working-packages/wp6/D6.3_GREENSURGE-WP6-guide-FINAL.pdf. (Accessed 12 September 2017).

Baró, F., Gómez-Baggethun, E., 2017. Assessing the potential of regulating ecosystem services as nature-based solutions in urban areas. In: Kabisch, N., Korn, H., Stadler, J., Bonn, A. (Eds.), 2017. Nature-Based Solutions to Climate Change Adaptation in Urban Areas. Linkages Between Science, Policy and Practice. Springer Theory and Practice of Urban Sustainability Transitions, pp. 139-158.

Baró, F., Chaparro, L., Gómez-Baggethun, E., Langemeyer, J., Nowak, D.J., Terradas, J., 2014. Contribution of ecosystem services to air quality and climate change mitigation policies: the case of urban forests in Barcelona, Spain. Ambio 43, 466-479.

Bentsen, P., Linholst, A.C., Konijnendijk, C.C., 2010. Reviewing eight years of Urban Forestry \& Urban Greening: taking stock, looking ahead. Urban For. Urban Greening 9, 273-280.

Buijs, A., Elands, B., Havik, G., Ambrose-Oji, B., Gerőházi, E., van der Jagt, A., Mattijssen, T., Steen Møller, M., Vierikko, K., 2016. Innovative Governance of Urban Green Spaces. Learning from 18 Innovative Examples Across Europe. Available at: http:// greensurge.eu/working-packages/wp6/files/Innovative_Governance_of_Urban_ Green Spaces - Deliverable 6.2.pdf. (Accessed 12 September 2017)

Buizer, M., Elands, B., Mattijssen, T., van der Jagt, A., Ambrose, B., Gerőházi É, Santos, A., Steen Møller, M., 2015. The Governance of Urban Green Spaces in Selected EU-Cities. Policies, Practices, Actors, Topics. GREEN SURGE Project Deliverable 6.1. University of Copenhagen, Copenhagen. Available at: http://greensurge.eu/working-packages/ wp6/files/Buizer_et_al_2015_D6.1_GREEN_SURGE_The_governance_of_urban_green spaces in selected EU cities.pdf. (Accessed 12 September 2017).

Di Matteo, Nardi, P., Ceci, P., Bajocco, S., Perini, L., Herrero-Corral, G., Gabiña, D., Scarascia Mugnozza, G., 2015. Linking the forest research in the Mediterranean area: a framework to improve research capacities and cooperation. For. Policy Econ. 50, 292-301.

Di Nardo, F., Saulle, R., La Torre, G., 2010. Green areas and health outcomes: a systematic 
review of the scientific literature. Ital. J. Public Health 7 (4), 402-413.

Diffenbaugh, N.S., Giorgi, F., 2012. Climate change hotspots in the CMIP5 global climate model ensemble. Climatic Change 114 (3-4), 813-822.

EC, 2011. Communication from the Commission to the European Parliament, the Council, the Economic and Social Committee and the Committee of the Regions. Our Life Insurance, Our Natural Capital: An EU Biodiversity Strategy to 2020. COM(2011) 244 Final.

EC, 2013a. An EU Strategy on Adaptation to Climate Change. COM(2013) 216 Final.

EC, 2013b. Communication from the Commission to the European Parliament, the Council, the European Economic and Social Committee and the Committee of the Regions. Green Infrastructure (GI) -Enhancing Europe's Natural Capital. COM(2013) 249 Final.

EC, 2017. Nature-based Solutions. Available at: https://ec.europa.eu/research/ environment/index.cfm?pg = nbs. (Accessed 22 September, 2017).

EEA, 2015. SOER 2015-The european environment ?state and outlook 2015. Synthesis Report. . Available at: https://www.eea.europa.eu/soer\#tab-synthesis-report. (Accessed 12 September 2017).

EEA, 2016. Air Quality in Europe -2016 Report, 1-83. . Available at: https://www.eea europa.eu/publications/air-quality-in-europe-2016. (Accessed 26 September 2017).

FAO, 2013. State of Mediterranean Forests 2013. FAO, pp. 1-183.

FAO, 2016. Guidelines on Urban and Peri-urban Forestry, by F. Salbitano, S., Borelli, M., Conigliaro, Y. Chen. FAO Forestry Paper No. 178. Food and Agriculture Organization of the United Nations, Rome.

FAO, 2017. Working Group on Urban and Peri-urban Forestry. Available at: http://www. fao.org/forestry/silva-mediterranea/88929/en/. (Accessed 21 September 2017).

Gómez-Baggethun, E., Barton, D.N., 2013. Classifying and valuing ecosystem services for urban planning. Ecol. Econ. 86, 235-245.

Geneletti, D., Zardo, L., 2016. Ecosystem-based adaption in cities: an analysis of European urban climate adaptation plans. Land Use Policy 50, 38-47.

Hansmann, R., Whitehead, I., Krajter Ostoić, S., Živojinović, I., Stojanovska, M., Jones, N., Bernasconi, A., Benamar, S., Lelieveld, C., Barstad, J., 2016. Partnerships for urban forestry and green infrastructure delivering services to people and the environment: a review on what they are and aim to achieve. SEEFOR 7 (1), 9-19.

Hiemstra, J., Saaroni, H., Amorim, J.H., 2017. The urban heat island: thermal comfort and the role of urban greening. Chapter 2. In: In: Pearlmutter, D., Calfapietra, C., Roeland, S., O'Brien, L., Krajter Ostoić, S., Sanesi, G., Alonso del Amo, R. (Eds.), The Urban Forest. Cultivating Green Infrastructure for People and the Environment, vol. 7. Springer, Future City, pp. 1-351.

James, P., Tzoulas, K., Adams, M.D., Barber, A., Box, J., Breuste, J., Elmqvist, T., Frith, M., Gordon, C., Greening, K.L., Handley, J., Haworth, S., Kazmierczak, A.E., Johnston, M., Korpela, K., Moretti, M., Niemelä, J., Pauleit, S., Roe, M.H., Sadler, J.P., Ward Thompson, C., 2009. Towards an integrated understanding of green space in the European built environment. Urban For. Urban Greening 8, 65-75.

Kabisch, N., Qureshi, S., Haase, D., 2015. Human-environment interactions in urban green space - A systematic review of contemporary issues and prospects for future research. Environ. Impact Assess. Rev. 50, 25-34.

Nature-based solutions to climate change adaptation in urban areas. In: Kabisch, N., Korn, H., Stadler, J., Bonn, A. (Eds.), Linkages Between Science, Policy and Practice. Springer, Theory and Practice of Urban Sustainability Transitions, pp. 1-342.

Kazmierczak, A., Carter, J., 2010. Adaptation to Climate Change Using Green and Blue Infrastructure. A Database of Case Studies. University of Manchester, GR aBS project. Available at: http://orca.cf.ac.uk/64906/1/Database_Final_no_hyperlinks.pdf. (Accessed 12 September 2017).

Konijnendijk, C.C., Ricard, R.M., Kenney, A., Randrup, T.B., 2006. Defining urban forestry - a comparative perspective of North America and Europe. Urban For. Urban Greening 4, 83-103.

Konijnendijk, C.C., Annerstedt, M., Nielsen, A.B., Maruthaveeran, S., 2013. Benefits of urban parks: a systematic review. A Report for IPFRA. IFPRA.

Konijnendijk, C.C., 2003. A decade of urban forestry in Europe. Forest Policy Econ. 5, 173-186.

Krajter Ostoić, S., Konijnendijk van den Bosch, C.C., 2015. Exploring global scientific discourses on urban forestry. Urban For. Urban Greening 14, 129-138.

Krajter Ostoić, S., Posavec, S., Vuletić, D., Stevanov, M., 2014. Valuation of urban forest benefits: a literature review. Works Croatian For. Res. Inst. 45 (2), 161-172.

Krajter Ostoić, S., Konijnendijk van den Bosch, C.C., Vuletić, D., Stevanov, M., Živojinović, I., Mutabdžija-Bećirović, S., Lazarević, J., Stojanova, B., Blagojević, D., Stojanovska, M., Nevenić, R., Pezdevšek Malovrh, Š., 2017. Citizensć perception of and satisfaction with urban forests and green space: results from selected Southeast European cities. Urban For. Urban Greening 23, 93-103.

López-Mosquera, N., Sánchez, M., 2011. Emotional and satisfaction benefits to visitors as explanatory factors in the monetary valuation of environmental goods. An application to periurban green spaces. Land Use Policy 28 (1), 151-166.

Lawrence, A., De Vreese, R., Johnson, M., Konijnedijk van den Bosch, C.C., Sanesi, G., 2013. Urban forest governance: towards a framework for comparing approaches. Urban For. Urban Greening 12 (4), 464-473.

Letina, S., 2017. Introduction to Social Network Analysis. Co-authorship of Scientists from Three Fields of Social Sciences Between 1992 and 2012. Hrvatska sveučilišna naklada, Zagreb, pp. 290 (in Croatian).

Manes, F., Salvatori, E., La Torre, G., Villari, P., Vitale, M., Biscontini, D., Incerti, G., 2008. Urban green and its relation with air pollution: ecological studies in the metropolitan area of Rome. Italian J. Public Health 5 (4), 278-283.

Mittermeir, R.A., Robles Gil, P., Hoffman, M., Pilgrim, J., Brooks, T., Goettsch Mittermeir, C., Lamoreux, J., da Fonseca, G.A.B., 2004. Hotspots Revisited: earth's biologically richest and most endangered terrestrial ecoregion. Conserv. Int. 1-392.

Morancho, A.B., 2003. A hedonic valuation of urban green areas. Landscape Urban Plann. 66 (1), 35-41.

Nardi, P., Di Matteo, G., Palahi, M., Scarascia Mugnozza, G., 2016. 2016. structure and evolution of mediterranean forest research: a science mapping approach. PLoS One. http://dx.doi.org/10.1371/journal.pone.0155016.

Nielsen, A.B., van den Bosch, M., Sreetheran, M., Konijnendijk van den Bosch, C., 2014. Species richness in urban parks and its drivers: a review of empirical evidence. Urban Ecosyst. 17 (1), 305-327.

O’Brien, L., De Vreese, R., Kern, M., Sievänen, T., Stojanova, B., Atmiş, E., 2017. Cultural ecosystem benefits of urban and peri-urban green infrastructure across different European countries. Urban For. Urban Greening 24, 236-248.

Paoletti, E., 2009. Ozone and urban forests in Italy. Environ. Pollut. 157, 1506-1512.

Pauleit, S., Zölch, T., Hansen, R., Randrup, T.B., Konijnendijk van den Bosch, C., 2017. Nature-based solutions and climate change- four shades of green. In: Kabisch, N., Korn, H., Stadler, J., Bonn, A. (Eds.), Nature-based Solutions to Climate Change Adaptation in Urban Areas. Linkages Between Science, Policy and Practice. Springer, Theory and Practice of Urban Sustainability Transitions, pp. 29-49.

Pearlmutter, D., Calfapietra, C., Samson, R., O’Brien, L., Krajter Ostoić, S., Sanesi, G., Alonso del Amo, R. (Eds.), 2017. The Urban Forest. Cultivating Green Infrastructure for People and the Environment, vol. 7. Springer, Future City, pp. 1-351.

Petticrew, M., 2001. Systematic reviews from astronomy to zoology: myths and misconceptions. BMJ 322, 98-101.

Plan Bleu, 2013. Mediterranean Strategy for Sustainable Development Follow-Up. Main Indicators. 2013 Update.

Randrup, T., Konijnendijk, C., Dobbertin, M.K., Prüller, R., 2005. The concept of urban forestry in Europe. Chapter 1. In: Konijnendijk, C.C., Nilsson, K., Randrup, T.B., Schipperijn, J. (Eds.), Urban Forests and Trees. Springer, pp. 9-21.

Raymond, C.M., Berry, P., Breil, M., Nita, M.R., Kabisch, N., de Bel, M., Enzi, V., Frantzeskaki, N., Geneletti, D., Cardinaletti, M., Lovinger, L., Basnou, C., Monteiro, A., Robrecht, H., Sgrigna, G., Munari, L., Calfapietra, C., 2017. An Impact Evaluation Framework to Support Planning and Evaluation of Nature-based Solutions Projects. Report Prepared by the EKLIPSE Expert Working Group on Nature-based Solutions to Promote Climate Resilience in Urban Areas. Centre for Ecology \& Hydrology, Wallingford, United Kingdom.

Rogers, K., Andreucci, M.-B., Jones, N., Japelj, A., Vranic, P., 2017. The value of valuing: recognizing the benefits of the urban forest. Chapter 21. In: In: Pearlmutter, D., Calfapietra, C., Samson, R., O’Brien, L., Krajter Ostoić, S., Sanesi, G., Alonso del Amo, R. (Eds.), The Urban Forest. Cultivating Green Infrastructure for People and the Environment, vol. 7. Springer, Future City, pp. 283-299.

Roy, S., Byrne, J., Pickering, C., 2012. A systematic quantitative review of urban tree benefits, costs, and assessment methods across cities in different climatic zones. Urban For. Urban Greening 11, 351-363.

Rupprecht, C.D.D., Byrne, J.A., 2014. Informal urban greenspace: a typology and trilingual systematic review of its role for urban residents and trends in the literature. Urban For. Urban Greening 13, 597-611.

Salvati, L., Gargiulo Morelli, V., 2014. Unveiling urban sprawl in the Mediterranean region: towards a latent urban transformation? Int. J. Urban Regional Res. 38 (6), 1935-1953.

Samson, R., Grote, R., Calfapietra, C., Cariñanos, P., Fares, S., Paoletti, E., Tiwary, A., 2017. Urban trees and their relation to air pollution. In: In: Pearlmutter, D., Calfapietra, C., Samson, R., O’Brien, L., Krajter Ostoić, S., Sanesi, G., Alonso del Amo, R. (Eds.), The Urban Forest. Cultivating Green Infrastructure for People and the Environment, vol. 7. Springer, Future City, pp. 21-30.

Sgrigna, G., Sæbø, A., Gawronski, S., Popek, R., Calfaprietra, C., 2015. Particulate matter deposition on Quercus ilex leaves in an industrial city of central Italy. Environ. Pollut. 197, 187-194.

Sreetheran, M., Konijnendijk van den Bosch, C.C., 2014. A socio-ecological exploration of fear of crime in urban green spaces - a systematic review. Urban For. Urban Greening 13, 1-18.

Thomson Reuters, 2012. Essential Science Indicators. Top 20 Countries in ALL Fields, 2001-August 31, 2011. Available at: http://archive.sciencewatch.com/dr/cou/2011/ 11 decALL/(1/8/2017).

UNEP/MAP, 2016. Mediterranean Strategy for Sustainable Development 2016-2025. Plan Bleu, Regional Activity Centre, Valbonne. Available at: https://planbleu.org/ sites/default/files/publications/mssd_2016-2025_final.pdf. (Accessed 20 September 2017).

van Weijen, D., 2012. The Language of (future) Scientific Communication. Research Trends 31. Available online: https://www.researchtrends.com/issue-31-november2012/the-language-of-future-scientific-communication/(1/8/2017).

Velarde, M.D., Fry, G., Tveit, M., 2007. Health effects of viewing landscapes - landscape types in environmental psychology. Urban For. Urban Greening 6, 199-212.

WHO, 2017. Burden of Non-communicable Diseases in the Eastern Mediterranean. Available at: http://www.emro.who.int/noncommunicable-diseases/publications/ burden-of-noncommunicable-diseases-in-the-eastern-mediterranean-region.html. (Accessed 25 September 2017). 